\title{
The Effect of Mocaf Substitution on Crispness and Organoleptic Quality of Milk Sticks
}

\author{
Dyah Nurul Afiyaha, Riska Nurtantyo Sarbini ${ }^{b}$ \\ aDepartment of Animal Science, Faculty of Agriculture, Kadiri Islamic University, Jalan Sersan Soeharmadji No 38 Kediri, East Java, \\ Indonesia \\ ${ }^{b}$ Department of Computer Engineering, Faculty of Engineering, Kadiri Islamic University, Jalan Sersan Soeharmadji No 38 Kediri, East Java, \\ Indonesia \\ email:먹ahnurula@gmail.com, ${ }^{b}$ riskanurtantyosarbini@gmail.com
}

\begin{tabular}{l} 
A R T I C L E I N F O \\
\hline Article history: \\
Received 13 October 2021 \\
Revised 28 October 2021 \\
Accepted 28 December 2021 \\
Available online 31 December \\
2021
\end{tabular}

Keywords:

Crunchy

Flour

Milk

Mocaf Sticks

IEEE style in citing this article:

D.N. Afiyah and R.N.,

Sarbini.," Jurnal Ternak, vol.

12, no. 2, pp. 49 - 53, 2021.

\section{A B S T R A C T}

Milk sticks are one of the dairy products that are served in the form of snacks. One of the ingredients added in making milk sticks is wheat flour which has a high amylose content. It causes the resulting milk sticks to be less crunchy. It is necessary to substitute flour with low amylose content, namely mocaf (Modified Cassava Flour). This research objective was to determine the effect of mocaf on the level of crispness and organoleptic quality of milk sticks. Milk sticks was made in animal science laboratory UNISKA Kediri by adding different percentage of flour: P0 (100\% wheat flour), P1 (90\% wheat flour and 10\% mocaf), P2 (80\% wheat flour and 20\% mocaf), P3 (70\% wheat flour and 30\% mocaf), and P4 (60\% wheat flour and $40 \%$ mocaf) in six replications. This research using completely randomized design (CRD). These results indicated that the substitution of mocaf in the manufacture of milk sticks could reduce the moisture content of the milk sticks so that the substitution of mocaf could increase the crispness. The organoleptic assessment was carried out on the parameters of color, taste, and crispness. There were no significant differences between the color and taste parameters, while the crispness showed that P0 was not significantly different from P1, but it was significantly different from $\mathrm{P} 2, \mathrm{P} 3$, and $\mathrm{P} 4$.

\section{Introduction}

Milk is a livestock product that is easily damaged. It is due to the high nutrients in milk. The main component of milk is water. The water contained in milk is $87.90 \%$, and the dry matter content in milk is $12.10 \%$, fat is $3.45 \%$, lactose is $4.60 \%$, casein is $2.70 \%$, protein is $3.20 \%$, and vitamins and minerals are $0.85 \%$ [1]. The water component is high enough to make milk susceptible to damage caused by microorganisms. As a result of these microorganisms, fresh milk has a short shelf life. Thus, it is necessary to process milk to increase the shelf life of milk. One of the dairy products that have a relatively long shelf life is milk sticks.

Milk stick is one of the dairy products served in the form of snacks that have long slices, long flats and made from milk, wheat flour, tapioca flour, eggs, and water, which are processed by frying to produce a savory taste and crunchy texture [2]. Milk sticks are long and have a golden yellow color after frying. The essential ingredients for milk sticks are flour, margarine, sugar, salt, and eggs. The added ingredients, especially wheat flour, have high amylose content, which causes the resulting milk sticks less crunchy. Therefore, it is necessary to substitute flour with low amylose content, named mocaf. 
Modified Cassava Flour (Mocaf) is a derivative product of cassava flour that uses the modification principle of cassava cells by fermentation. The amylose content in mocaf is $19 \%$. It is far below wheat flour which reaches $28 \%$ [3]. The crisper the resulting product, the lower the hardness level. According to [4], high amylose flour has a more complicated, adhesive, and compact flour gel than low and medium amylose flour. While flour with low amylose content has high amylopectin content, the amylopectin stimulates the puffing process until the resulting food product is crispy, light, porous, and crunchy [5]. Based on the description above, this research objective was to determine the effect of giving mocaf on the level of crispness and organoleptic quality of milk sticks.

\section{Research Methods}

This research was conducted at the Laboratory of Animal Husbandry, Faculty of Agriculture, Kadiri Islamic University, from January until February 2021. The ingredients needed were two liters of milk, 150 grams of tapioca flour, 200 grams of wheat flour, garlic, salt, vinegar, cheese, an egg, and margarine. The tools needed were a pan, thermometer, sieve, basin, dough grinder or noodle mill, frying pan, and stove.

The procedure for making milk sticks was pasteurizing fresh milk at $63^{\circ} \mathrm{Cfor} 15$ minutes and lowering the temperature to $40^{\circ} \mathrm{C}$ The addition of vinegar to pasteurized milk homogenized then allowed to stand for \pm 10 minutes so that clumps of milk curd formed. After that, drained the milk curd and added the mocaf with sizes P0 (100\% wheat flour), P1 (90\% wheat flour and 10\% mocaf), P2 (80\% wheat flour and 20\% mocaf), P3 (70\% wheat flour and 30\% mocaf), and P4 (60\% wheat flour and 40\% mocaf). Each treatment was repeated six times. Then, the researchers added sugar and salt and homogenized them until evenly distributed. After that, the researcher added one egg, melted margarine, and homogenized them until evenly distributed.

The next step was mixing until the entire dough was homogeneous and smooth (tried to make the dough smooth) so that when the dough stick was printed, the milk did not break. Printing was done on the dough using a mue roll which was then cut lengthwise with a size of $\pm 10 \mathrm{~cm}$. The dough was fried by putting it in oil at $180^{\circ} \mathrm{Cfor} \pm 5$ minutes. Ripe milk sticks were drained and packaged [6].

The parameters observed included testing the moisture content with a sample weight of 1 gram [7], physical analysis of crispness by stress test using a texture analyzer [8], and organoleptic analysis, which included color, taste, and crispness. The research was designed using a completely randomized design (CRD).

\section{Results and Discussion}

Milk stick is one of the dairy products served in the form of snacks that have long slices, long flats, and are made from milk curd, wheat flour, eggs, and water which are processed by frying to produce a savory taste crunchy texture [9]. The main ingredient of milk sticks is milk curd produced by pasteurizing milk and coagulating with vinegar. Milk contains a protein in the form of casein which can experience clumping. Clumping milk in making milk tofu can be done in various ways, including with acid, and can be accelerated by heating [1]. The dough that has been formed will be continued in the frying process until the milk sticks are cooked yellow. The homogeneous dough is molded, cut lengthwise, and fried in hot oil at $180^{\circ} \mathrm{Q}[10]$.

Table 1. Moisture Content of Milk Sticks with Mocaf Substitution

\begin{tabular}{cc}
\hline Parameter & Moisture Content $(\%)$ \\
\hline P0 & $8.32^{\mathrm{a}} \pm 0.32$ \\
P1 & $8.46^{\mathrm{a}} \pm 0.56$ \\
P2 & $7.72^{\mathrm{b}} \pm 0.55$ \\
P3 & $7.58^{\mathrm{b}} \pm 0.92$ \\
P4 & $7.12^{\mathrm{b}} \pm 0.49$ \\
\hline
\end{tabular}


*Significant different by rows ${ }^{*} \mathrm{P}<0.01 ;{ }^{* *} \mathrm{P}<0.05$

${ }^{* *}$ P0 (100\% wheat flour), P1 (90\% wheat flour dan 10\% mocaf), P2 (80\% wheat flour dan $20 \%$ mocaf), P3 (70\% wheat flour dan 30\% mocaf), dan P4 (60\% wheat flour dan $40 \%$ mocaf)

Sticks are a type of snack made from wheat flour which contains gluten and starch. According to [11], wheat flour is flour derived from wheat, with the most significant component being starch, about $70 \%$ consisting of amylose and amylopectin. The amount of amylose content in starch is about $20 \%$ [11]. According to [12], starch is one of the ingredients in wheat flour that makes sticks crispy. This starch content can be replaced by local flour, such as mocaf. The starch content of wheat flour is lower, $60-68 \%$, while mocaf has a starch content of $87 \%$. Therefore, wheat flour can be substituted with flour with almost the same starch content, such as mocaf.

Mocaf is a modified cassava flour made from fermented cassava. The mocaf components are different from the wheat flour components. The gluten content is not owned by mocaf but by wheat flour as an ingredient that determines food elasticity. Mocaf contains $23.03 \%$ amylose and $87 \%$ amylopectin. Amylose gives a complex effect while amylopectin softens the dough [13]. In foodstuffs that use mocaf before frying, the bonds are soft and flexible. However, after frying, they become hard and crispy [14].

Milk sticks made with mocaf substitution in the form of P0 (100\% wheat flour), P1 (90\% wheat flour and 10\% mocaf), P2 (80\% wheat flour and 20\% mocaf), P3 (70\% wheat flour and 30\% mocaf), and P4 (60\% wheat flour and 40\% mocaf) were analyzed for moisture content, and the results were as shown in Table 1.

Moisture content is an essential factor that affects crispness. Higher product moisture content results in lower crispness [15]. The moisture content of P0 was not significantly different from that of P1 but significantly different from that of P2, P3, and P4. These results indicated that the substitution of mocaf in the manufacture of milk sticks could reduce the moisture content of milk sticks.

Table 2. Crunchy Milk Sticks with Mocaf Substitution

\begin{tabular}{cc}
\hline Parameter & Crispness $(\mathrm{mm})$ \\
\hline P0 & $1.85^{\mathrm{a}} \pm 0.02$ \\
P1 & $1.79^{\mathrm{a}} \pm 0.16$ \\
P2 & $1.72^{\mathrm{a}} \pm 0.35$ \\
P3 & $2.58^{\mathrm{b}} \pm 0.42$ \\
P4 & $2.12^{\mathrm{b}} \pm 0.04$ \\
\hline
\end{tabular}

*Significant different by rows ${ }^{*} \mathrm{P}<0.01 ;{ }^{* *} \mathrm{P}<0.05$

${ }^{* *}$ P0 (100\% wheat flour), P1 (90\% wheat flour dan 10\% mocaf), P2 (80\% wheat flour dan $20 \%$ mocaf), P3 (70\% wheat flour dan 30\% mocaf), dan P4 (60\% wheat flour dan $40 \%$ mocaf)

The increase in the mocaf proportion decreased the moisture content caused by a starch-protein matrix that could withstand water evaporation during the drying process. Therefore, much water was retained in the material and could not be measured as moisture content [16]. The existence of waterbinding competition between starch, protein, and fiber would also interfere with the adequacy of starch gelatinization. Therefore, less water entered the starch granules, and the moisture content became low. In addition, the high proportion of mocaf caused the amylopectin content of the dough to be lower so that the water released was more significant, and the moisture content of the milk sticks was lower [17].

Based on the ANOVA test, mocaf substitution at P0 was not significantly different from P1 and P2, but it was significantly different from P3 and P4. These results indicated that the substitution of mocaf in the manufacture of milk sticks could increase the crispness. It was also related to the moisture content, where the less moisture content caused the more outstanding crispness. It was due to the higher 
expansion power of the milk sticks so that the pores formed were getting bigger, and the linear distance required for the milk sticks to break was getting bigger.

The organoleptic assessment was carried out on the parameters of color, taste, and crispness of milk sticks with mocaf substitution. The assessment results of 30 semi-trained panelists on color parameters showed no significant difference in milk sticks substituted with mocaf. The color produced on milk sticks was yellow to brownish-yellow. It was due to the presence of sugar and protein components from milk which was degraded during frying, causing a slightly brownish color [18].

Taste is a critical parameter for consumers' acceptance, where taste is the main parameter chosen by consumers' unacceptance, especially of new products [19]. The assessment results of the taste parameters showed that there was no significant difference in milk sticks substituted with mocaf. The resulting taste in milk sticks was milky. The substitution of mocaf used dominated and covered the flour. Thus, the savory taste of the sticks as the mocaf increases faded.

Table 3. Organoleptic Quality of Milk Sticks with Mocaf Substitution

\begin{tabular}{cccc}
\hline Parameter & Color & Taste & Crispness \\
\hline P0 & $3.82^{\mathrm{a}} \pm 0.62$ & $3.12^{\mathrm{a}} \pm 1.02$ & $3.45^{\mathrm{a}} \pm 0.32$ \\
P1 & $3.67^{\mathrm{a}} \pm 0.51$ & $3.41^{\mathrm{a}} \pm 1.11$ & $3.49^{\mathrm{a}} \pm 0.21$ \\
P2 & $3.12^{\mathrm{a}} \pm 0.83$ & $3.13^{\mathrm{a}} \pm 0.75$ & $4.42^{\mathrm{b}} \pm 0.35$ \\
P3 & $3.48^{\mathrm{a}} \pm 0.79$ & $3.05^{\mathrm{a}} \pm 0.63$ & $4.34^{\mathrm{b}} \pm 0.58$ \\
P4 & $3.62^{\mathrm{a}} \pm 0.74$ & $3.32^{\mathrm{a}} \pm 1.04$ & $4.56^{\mathrm{b}} \pm 0.75$ \\
\hline
\end{tabular}

*Significant different by rows ${ }^{*} \mathrm{P}<0.01 ;{ }^{* *} \mathrm{P}<0.05$

${ }^{* *}$ P0 (100\% wheat flour), P1 (90\% wheat flour dan 10\% mocaf), P2 (80\% wheat flour dan $20 \%$ mocaf), P3 (70\% wheat flour dan 30\% mocaf), dan P4 (60\% wheat flour dan $40 \%$ mocaf)

[20] states that the crispness of the sticks is one of the crucial factors determining the best stick results. The crispness of the sticks was influenced by the use of wheat flour and the frying process. Assessment of the crispness parameter showed that P0 was not significantly different from P1, but it was significantly different from P2, P3, and P4. Hardness in milk stick products could also be affected by protein, gluten formation, fat content, and starch granules. In substitution of mocaf, milk sticks did not have as much gluten as wheat flour, affecting the hardness of the resulting cookies [21].

\section{Conclusion}

These results indicate that the substitution of mocaf in the manufacture of milk sticks can reduce the moisture content of the milk sticks. On the other word, substitution of mocaf can increase the crispness. The organoleptic assessment was carried out on the parameters of color, taste, and crispness. There were no significant differences between the color and taste parameters, while the crispness showed that P0 was not significantly different from P1 but significantly different from P2, P3, and P4

\section{Reference}

[1] Anggraini R.P., A.H.D. Raharjo dan R.S.S. Santosa. 2013. Effect of Bromelin Enzyme Levels from Cooked Pineapple in The Manufacture of Milk Tofu on Yield and Suppity of Milk Tofu. Jurnal Ilmiah Peternakan. 1 (2): 507-513.

[2] Siswanti, P.Y. Agnesia, R. Baskara. 2017. Utilization of Meat and Bones of Bloated Fish (Rastrelliger kanagurta) In The Manufacture of Stick Snacks. Jurnal Teknologi Hasil Pertanian. 10 (1): 41-49

[3] Pradipta, I. B. Y. V., Widya D. R.P. 2015. Effect of Proportion of Wheat Flour and Green Bean Flour As well as Substitution with Bran Flour In Biscuits. Jurnal Pangan dan Agroindustri Vol. 3 No. 3 p. $793-802$ 
[4] Lin J.H., Harinder S., Yi T.C.,dan Yung H.C.2011. Factor analysis of the functional properties of rice flours from mutant genotypes. Food Chem $126: 1108-1114$

[5] Hersoelistyorini W., S. Asropah., Nurrahman. 2015. Long-Lasting Effects on Yield, Anthocyanin Levels, Vitamin E and Antioxidant Activity of Black Soybean Sprouts. Jurnal Unimus.

[6] Dewantara, A. 2020. Effect of Addition of Moringa Oleifera On Milk Sticks Reviewed from Fiber Levels, Yields, Texture and Crispness. Skripsi. Program Studi Peternakan, Universitas Brawijaya.

[7] Sudarmadji, S., B. Haryono dan Suhardi. 1997. Analytical Procedures for Food and Agriculture. Yogyakarta: Liberty.

[8] Saeleaw M, Schleining G. 2011. Effect of frying parameters on crispiness and sound emission of cassava crackers. J Food Eng 103: 229-236. DOI: 10.1016/j.foodeng.2010.10.010

[9] Siswanti., Aldila C.K., B. K. Anandito. 2016. Effect of Sodium Pyrophosphate Concentration (Na2H2P2O7) and Length of Immersion Against The Characteristics of Soy Sprout Flour. Jurnal Teknologi Hasil Pertanian. Vol IX No. 1

[10] Susanto, W.E., E.D. Kusumawati, A.T.N. Krisnaningsih, H. Leondro, D.P.P Hadiani. 2018. Training and Assistance in Afkir Milk Processing in Kemantren Jabung Village. Seminar Nasional Hasil Pengabdian.

[11] Belitz, H.D. dan Grosch, W. (1987). Food Chemistry. 2nd Ed. Springer

[12] Salim, Amil. 2011. Processing Cassava Flour Into Mocaf Flour. Yogyakarta : Lily Publisher.

[13] Abidin. 2009. Formulation Development, Production Process and Product Karasterization. Diakses Pada Tanggal 5 Agustus 2015

[14] Koswara, S. 2009. Processing of Various Crackers. Ebookpangan.com.

[15] Luyten H, van Vliet T. 2006. Acoustic emission, fracture behaviour and morphology of dry crispy foods, a discussion article. J Texture Stud 37: 221-240. DOI: 10.1111/j.17454603.2006.00049.x.

[16] Utomo, D. 2008. Fortification of Tortillas by Utilizing Crickets (Gryllus sp.) in order to improve community nutrition. Primordia. 4(1):23-38.

[17] Soewandi, B.M. 2012. Effect of Tapioca Proportions and Brown Rice Flour on Physical and Organoleptic Properties of Brown Rice Crackers

[18] Damayanti, M., W. Hersoelistyorini. 2020. Effect of The Addition of White Banana Flour On The Physical and Sensory Properties of Sticks. Jurnal Pangan dan Gizi Vol (No): 24-33, April 2020.

[19] Ramadani, W., W.H. Susanto. 2016. Making Crackers Cekeremes Study of Flour Proportions (Mocaf: Bungkil Kacang: Tapioka) As well as The Addition of CMC Concentration. Jurnal Pangan dan Agroindustri Vol. 4 No. 1 p.302-312, Januari 2016

[20] Kumara, S.W. 2016. Development of Onion Sticks Substitute Banana Skin Kepok (Musa paradisiaca) Supplemented Torbagun (Coleus amboinicus L.) For Women Premenstrual syndrome. (Skripsi). Fakultas Ekologi Manusia, Institut Pertanian Bogor

[21] Wijaya ,V.A. 2017. Effect of The Type of Soaking Solution on the Quality of Banana Flour Kepok (Musa paradisiaca) Applied to Cookie Products. (Skripsi), Fakultas Teknologi Pertanian. Universitas Katolik Soegijapranata Semarang. 